УДК 664.951

\title{
ИССЛЕДОВАНИЕ БИОТЕХНОЛОГИЧЕСКОГО ПРОЦЕССА \\ СОЗРЕВАНИЯ ФИЛЕ ОКУНЯ МОРСКОГО, ПОСОЛЕННОГО \\ С ИСПОЛЬЗОВАНИЕМ КОМПЛЕКСНОЙ ПИЩЕВОЙ ДОБАВКИ \\ «PRE-FISH», В ТЕХНОЛОГИИ ДЕЛИКАТЕСНОЙ \\ ПОДКОПЧЕННОЙ ПРОДУКЦИИ
}

\section{Лукина Елена Викторовна \\ аспирант}

Антонов Павел Владимирович

бакалавр

Научные руководители: Шокина Юлия Валерьевна

д.т.н., профессор

ФГАОУ ВО «Мурманский государственный технический университет»

\section{Шкуратова Евгения Борисовна}

к.т.н., начальник научно-организационного отдела Полярный филиал ФГБНУ «ВНИРО» («ПИНРО» им. Н.М. Книповича).

\begin{abstract}
Аннотация: исследовано влияние импортной комплексной пищевой добавки «Pre-Fish» (производства Германия) на биотехнологический процесс созревания соленого полуфабриката с низкой жирностью в технологии деликатесного рыбного подкопченного филе. Проведен анализ эффективности использованной добавки в сравнении с ферментным препаратом из гепатопанкреаса краба стригуна опилио (Chionoecetes opilio) разработки Полярного филиала ФГБНУ «ВНИРО» («ПИНРО» им. Н.М. Книповича). Установлены оптимальные концентрации комплексной пищевой добавки, гарантирующие формирование у готовой продукции органолептических признаков деликатесной продукции. При оптимизации технологических режимов посола использован математический метод нечеткой логики в программном пакете MatLab.
\end{abstract}

Ключевые слова: посол, созревание, слабосозревающее рыбное сырье, комплексная пищевая добавка, ферментный препарат. 


\title{
RESEARCH OF THE BIOTECHNOLOGICAL PROCESS \\ OF MATURATION OF SEA BASS FILLET, SALTED WITH THE USE OF A COMPLEX FOOD ADDITIVE «PRE-FISH», IN THE TECHNOLOGY OF DELICATESSEN SEMI-SMOKED PRODUCTS
}

\author{
Lukina Elena Viktorovna \\ Fntonov Pavel Vladimirovich \\ Scientific advisers: Shokina Yulia Valerievna \\ Shkuratova Evgenya Borisovna
}

\begin{abstract}
Pre-Fish» (produced in Germany) on the biotechnological process of maturation of salted semifinished product with low fat content in the technology of delicatessen smoked fish fillet is studied. The effectiveness of the used additive was analyzed in comparison with an enzyme preparation from the hepatopancreas of the opilio crab developed by the Polar Branch of the VNIRO Federal State Budgetary Research University (PINRO named after N. M. Knipovich). The optimal concentrations of a complex food additive have been established, which guarantee the formation of organoleptic signs of delicatessen products in the finished product.
\end{abstract}

Key words: salting, maturation, weakly maturing fish raw materials, a complex food additive, an enzyme preparation.

Ключевой проблемой при изготовлении подкопченного филе из маложирного рыбного сырья является проблема интенсификации биотехнологического процесса созревания соленого полуфабриката, в результате которого формируются все характерные органолептические признаки деликатесной продукции - аромат, вкус и нежная, сочная консистенция.

Как известно, маложирное рыбное сырье - треска, пикша, сайда, окунь морской, ставрида и др. - прекрасно подходят для изготовления продукции подкопченной, холодного и горячего копчения, однако, практически не используется в технологиях, основанных на созревании из-за недостатка триглицеридов в процессе гидролиза которых в тканях рыбы накапливаются жирные кислоты непосредственно участвующие в процессах созревания.

Для решения этой проблемы ученые Полярного филиала ФГБНУ «ВНИРО» («ПИНРО» им. Н.М. Книповича) совместно с учеными Мурманского 
государственного технического университета разработали технологию деликатесного рыбного подкопченного филе трески и сайды, использующую в качестве созревателя ферментный препарат из гапатопанкреаса краба-стригуна опилио (Chionoecetes opilio) [1, с. 3-5]. Исследователями были научно обоснованы оптимальные технологические режимы посола полуфабриката филе тресковых рыб - тузлучный (мокрый) способ посола, соотношение филе и тузлука, температура и концентрация тузлука, а также способ внесения ферментного препарата из гапатопанкреаса краба стригуна опилио (далее ФП ГПКС) и его оптимальная концентрация в тузлуке, длительность посола при выбранных условиях. Экспериментально была подтверждена высокая эффективность разработанного способа интенсификации созревания филе тресковых рыб [2, с. 126-137].

Однако к недостаткам разработанной технологии следует отнести, прежде всего, отсутствие в Российской Федерации промышленного производства ферментных препаратов, в частности, препарата из гепатопанкреаса краба-стригуна, что делает разработанную технологию малодоступной для российских рыбопреребатывающих предприятий.

Подавляющее большинство рыбопереабатывающих предприятий, специализирующихся на выпуске деликатесной рыбной продукции слабосоленой и подкпопченной - используют в настоящее время импортные пищевые добавки, широко представленные на отечественном рынке фирмамипосредниками. Лидирующие позиции занимают добавки китайского производства, представлены также высококачественные и полностью безопасные добавки европейских, в частности, немецких, производителей. Однако широкое применение качественных и безопасных добавок ограничивает их высокая стоимость, что существенно повышает риски химической контаминации пищевой продукции токсичными соединениями, что недопустимо.

О необходимости скорейшего создания отечественной производственной базы по выпуску добавок и ферментных препаратов заявлено как о приоритетной задачи на ближайшую перспективу в «Стратегии развития пищевой и перерабатывающей промышленности Российской Федерации на период до 2030 года» [3].

С учетом вышеизложенного цель исследований представляло совершенствование технологии деликатесного подкопченного филе окуня морского, характеризуемого пониженной жирностью, с использованием 
комплексной пищевой добавки, интенсифицирующей процесс созревания полуфабриката как на этапе посола, так и на этапе хранения готовой продукции до реализации.

Для достижения поставленной цели были сформулированы и успешно решены в работе следующие задачи:

- изучить по литературным данным используемые в производстве деликатесной слабосоленой и подкопченной рыбной продукции пищевые добавки (ПД) и ферментные препараты (ФП), сформулировать основные критерии их эффективности;

- провести исследование биохимических процессов, протекающих в тканях филе окуня морского на этапе посола полуфабриката с использованием созревателя натурального происхождения (ФПГПКС - контроль) и комплексной пищевой добавки «Pre-Fish» (производство Германия, реализуется на отечественном рынке $\mathrm{OOO}$ «Ваш технолог», г. Санкт-Петербург), а также на этапе хранения готовой продукции в зависимости от технологических режимов посола;

- на основе сравнительного анализа результатов исследования сформулировать рекомендации по использованию комплексной пищевой добавки (КПД) «Prer-Fish» в технологиях деликатесной рыбной продукции из слабо созревающего маложирного сырья.

В работе использованы физико-химические методы исследования по ГОСТ 7636-85 «Рыба, морские млекопитающие, морские беспозвоночные и продукты их переработки. Методы анализа» и отдельные нестандартные методики, органолептическая оценка продукции - по ГОСТ 7631-2008 «Рыба, нерыбные объекты и продукция из них. Методы определения органолептических и физических показателей».

В соответствии с требованиями ГОСТ Р 52499-2005 «Добавки пищевые. Термины и определения» пищевые добавки - это любое вещество или смесь веществ, не употребляемых человеком непосредственно в качестве пищи, преднамеренно вводимые в пищевой продукт в процессе его производства с технологической целью, включая придание ему определенных органолептических свойств и сохранение качества и безопасности в течение установочного срока годности или хранения.

В таблице 1 перечислены существующие функциональные классы пищевых добавок, а также назначение каждого из представленных классов. 


\section{ПЕРСПЕКТИВНЫЕ РАЗРАБОТКИ ПО ПРИОРИТЕТНЫМ НАПРАВЛЕНИЯМ РАЗВИТИЯ}

Регуляторы кислотности, к которым относятся цитраты, используют при посоле полуфабриката в технологиях рыбных пресервов и соленой рыбы для понижения $\mathrm{pH}$ и интенсификации созревания по механизму активации собственных тканевых ферментов сырья, оптимум $\mathrm{pH}$ действия которых находится в слабокислой области.

Цитраты входят в состав многих КПД, в том числе, эти соединения составляют основу КПД «Pre-Fish», которую производитель позиционирует как созреватель. Состав добавки представлен в таблице 2.

\section{Таблица 1}

Функциональные классы и названия пищевых добавок

\begin{tabular}{|c|c|}
\hline Функциональный класс & Назначение \\
\hline Кислоты & $\begin{array}{c}\text { Повышают кислотность и придают } \\
\text { кислый вкус пище }\end{array}$ \\
\hline $\begin{array}{c}\text { Регуляторы кислотности, кислоты, щелочи, } \\
\text { основания, буферы, регуляторы рН }\end{array}$ & Регулируют кислотность продукта \\
\hline $\begin{array}{c}\text { Вещества, препятствующе слеживанию или } \\
\text { комкованию, препятствующие затвердению и } \\
\text { разделяющие вещества }\end{array}$ & $\begin{array}{c}\text { Снижают способность частиц пищевого } \\
\text { продукта к прилипанию друг к другу }\end{array}$ \\
\hline Пеногасители & Предупреждают или снижают \\
образование пены
\end{tabular}




\section{ПЕРСПЕКТИВНЫЕ РАЗРАБОТКИ ПО ПРИОРИТЕТНЫМ НАПРАВЛЕНИЯМ РАЗВИТИЯ}

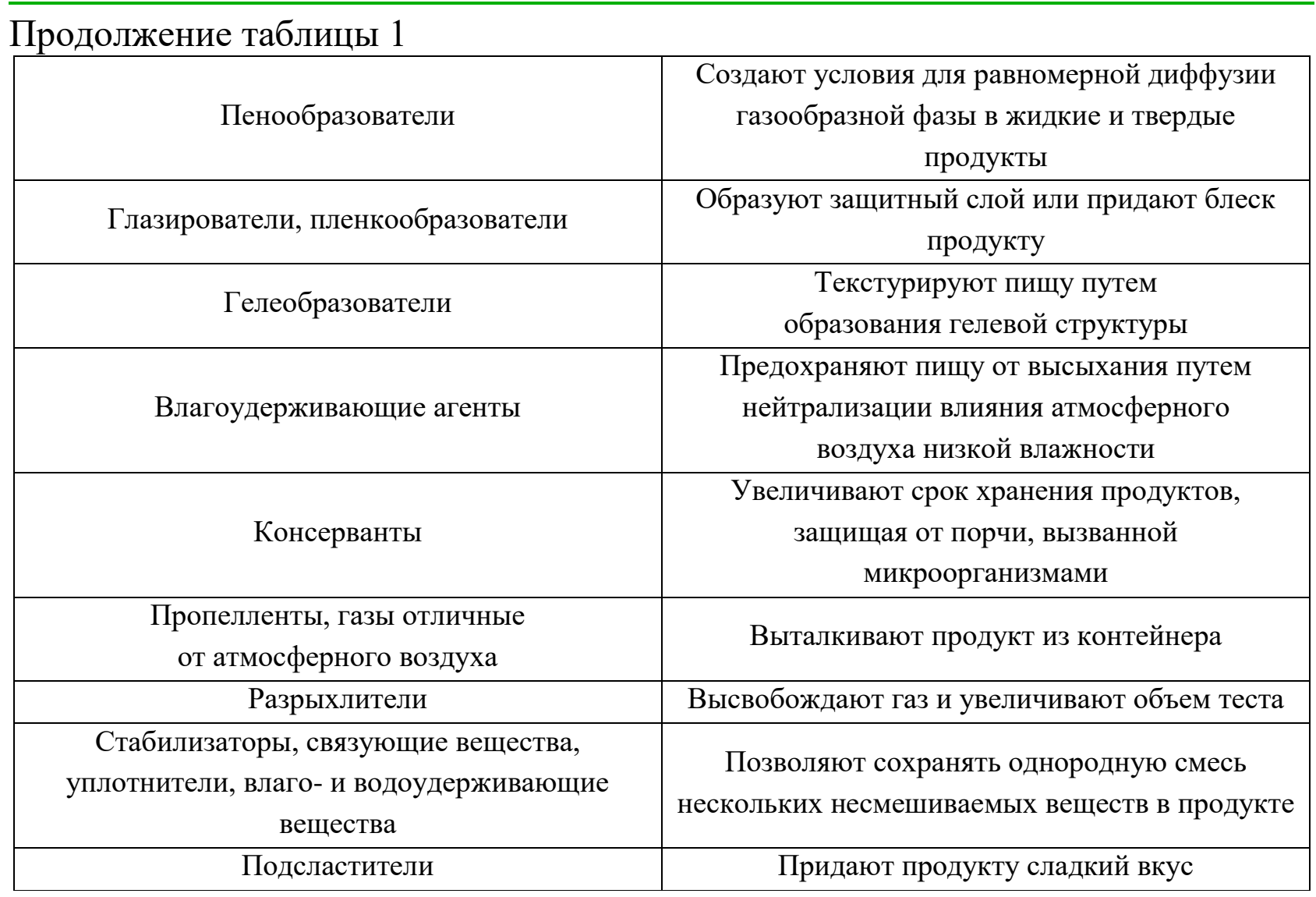

Таблица 2

\section{Состав пищевой добавки «Pre-Fish»}

\begin{tabular}{|c|c|}
\hline Тип КПД, рекомендуемая доза & Компнент КПД \\
\hline Регуляторы кислотности & $\begin{array}{c}\text { цитрат натрия (Е331), } \\
\text { лимонная кислота (Е330); }\end{array}$ \\
\hline Антиокислитель & $\begin{array}{c}\text { аскорбат кальция (Е302), } \\
\text { аскорбиноваякислдота (Е300); }\end{array}$ \\
\hline Стабилизатор & хлорид натрия \\
\hline Рекомендуемая доза & $\begin{array}{c}\text { от } 3 \text { до 5\% в солевом растворе, соотношение } \\
\text { рыба:тузлук } 2: 1, \text { температура посола } 7^{\circ} \mathrm{C}\end{array}$ \\
\hline
\end{tabular}

Как видно из таблицы 2, кроме цитрата в состав «Pre-Fish» входит также лимонная кислота, антиокислитель - аскорбат кальция, аскорбиновая кислота и хлорид натрия. Добавка полностью соответствует требованиям Федерального закона «О качестве и безопасности пищевых продуктов», рекомендуемые немецким производителем добавки нормы закладки при производстве соленой 
рыбопродукции соответствуют требованиям ФАО/ВОЗ комиссии «СОDEX ALIMENTARIUS», обеспечивая безопасное для здоровья человека содержание веществ в конечном продукте.

Ферментный препарат из гепатопанкреаса краба стригуна опилио, использованный в качестве образца-контроля при исследовании эффективности КПД «Pre-Fish» как созревателя, характеризуется протеолитической активностью в той или иной степени при всех значениях $\mathrm{pH}$. Разработчики отмечают максимум протеолитической активности ФПГПКС в нейтральной и слабощелочной зоне $\mathrm{pH}$ 7,0-8,5, с пиком активности при $\mathrm{pH} 7$ при температуре $50{ }^{\circ} \mathrm{C}$.

Температурный оптимум активности ФПГКС по отношению к используемым субстратам при $\mathrm{pH} 7$ составляет $50{ }^{\circ} \mathrm{C}$, при этом отмечена активность протеиназ в диапазоне низких температур - от 5 до $15{ }^{\circ} \mathrm{C}$ при $\mathrm{pH} 7$ [1, c. 5-7].

В настоящее время в Мурманской области по данным статистики в наибольшей степени перерабатываются треска и тресковые рыбы, остальной улов донного промысла - палтус, зубатки, скаты - перерабатывается в гораздо меньших объемах и с меньшей глубиной. Морской окунь является достаточно массовым объектом промысла в Баренцевом море и прекрасным сырьем для производства широкого ассортимента продукции - горячего и холодного копчения, консервов, рыбной кулинарии.

Ранее разработанная технология деликатесной подкопченной продукции, при использовании для получения коптильного дыма ИК-дымогенератора, позволяет производить не только продукт с улучшенными органолептическими свойствами, но и канцерогенно безопасный [1, с. 10-12]. С учетом вышеизложенного совершенствования технологии деликатесного подкопченного филе окуня морского представляется весьма актуальной исследовательской задачей.

Экспериментально установленный химический состав объекта исследования - филе окуня морского представлен в таблице 3. 
Таблица 3

\section{Химический состав филе окуня морского (опытная партия)}

\begin{tabular}{|c|c|c|c|c|c|c|c|c|}
\hline \multirow[t]{2}{*}{$\begin{array}{c}\text { Масса } \\
\text { филе, кг }\end{array}$} & \multicolumn{6}{|c|}{$\begin{array}{c}\text { Химический состав мышечной ткани филе окуня } \\
\text { морского, \% }\end{array}$} & \multirow{2}{*}{$\begin{array}{c}\text { Удельная } \\
\text { поверх- } \\
\text { ность } \\
\text { филе, } \\
\text { м²/кг }\end{array}$} & \multirow{2}{*}{$\begin{array}{c}\text { Тол- } \\
\text { щина } \\
\text { филе, } \\
\text { мм }\end{array}$} \\
\hline & вода & жир & $\begin{array}{c}\text { общий } \\
\text { азот } \\
\text { (OA) }\end{array}$ & $\begin{array}{c}\text { Небелко- } \\
\text { вый азот } \\
\text { (НБА) }\end{array}$ & $\begin{array}{c}\text { Истин- } \\
\text { ный } \\
\text { протеин } \\
\text { (ИП) }\end{array}$ & зола & & \\
\hline $325 \pm 25$ & $\begin{array}{c}76,13 \pm \\
3,84\end{array}$ & $\begin{array}{c}4,68 \pm \\
0,53\end{array}$ & $\begin{array}{c}3,13 \pm \\
0,13\end{array}$ & $0,24 \pm 0,03$ & $\begin{array}{c}18,06 \pm \\
0,12\end{array}$ & $\begin{array}{c}1,13 \pm \\
0,15\end{array}$ & $\begin{array}{l}\text { от } 0,18 \text { до } \\
0,25\end{array}$ & $\begin{array}{l}\text { от } 10 \\
\text { до } 14\end{array}$ \\
\hline $\mathrm{bBK}^{1}, \%$ & \multicolumn{8}{|c|}{23,72} \\
\hline БВЖК $^{2}, \%$ & \multicolumn{8}{|c|}{24,21} \\
\hline $\begin{array}{l}{ }^{1} \text { Белково-вс } \\
{ }^{1} \text { Белков-во }\end{array}$ & $\begin{array}{l}\text { й ко } \\
\text { кирс }\end{array}$ & $\begin{array}{l}\text { ициен } \\
\text { коэфс }\end{array}$ & & & & & & \\
\hline
\end{tabular}

На рис. 1 представлена технология подкопченного рыбного филе, которая усовершенствована на этапе посола полуфабриката, а именно в тузлук до посола рыбного филе вносят ФПГПКС или КПД «Pre-Fish». В обоих случаях в тузлук вносят бинарный консервант - бензоат натрия и сорбат калия, в массовой концентрации оговоренной производителем препарата, а именно $0,2 \%$.

Остальные условия посола - температура, соотношение рыбы и тузлука, тара для посола, размерно-массовая характеристика и химический состав рыбы поддерживали постоянными для исключения влияния на результат эксперимента. Условия посла приведены в таблице 4. 


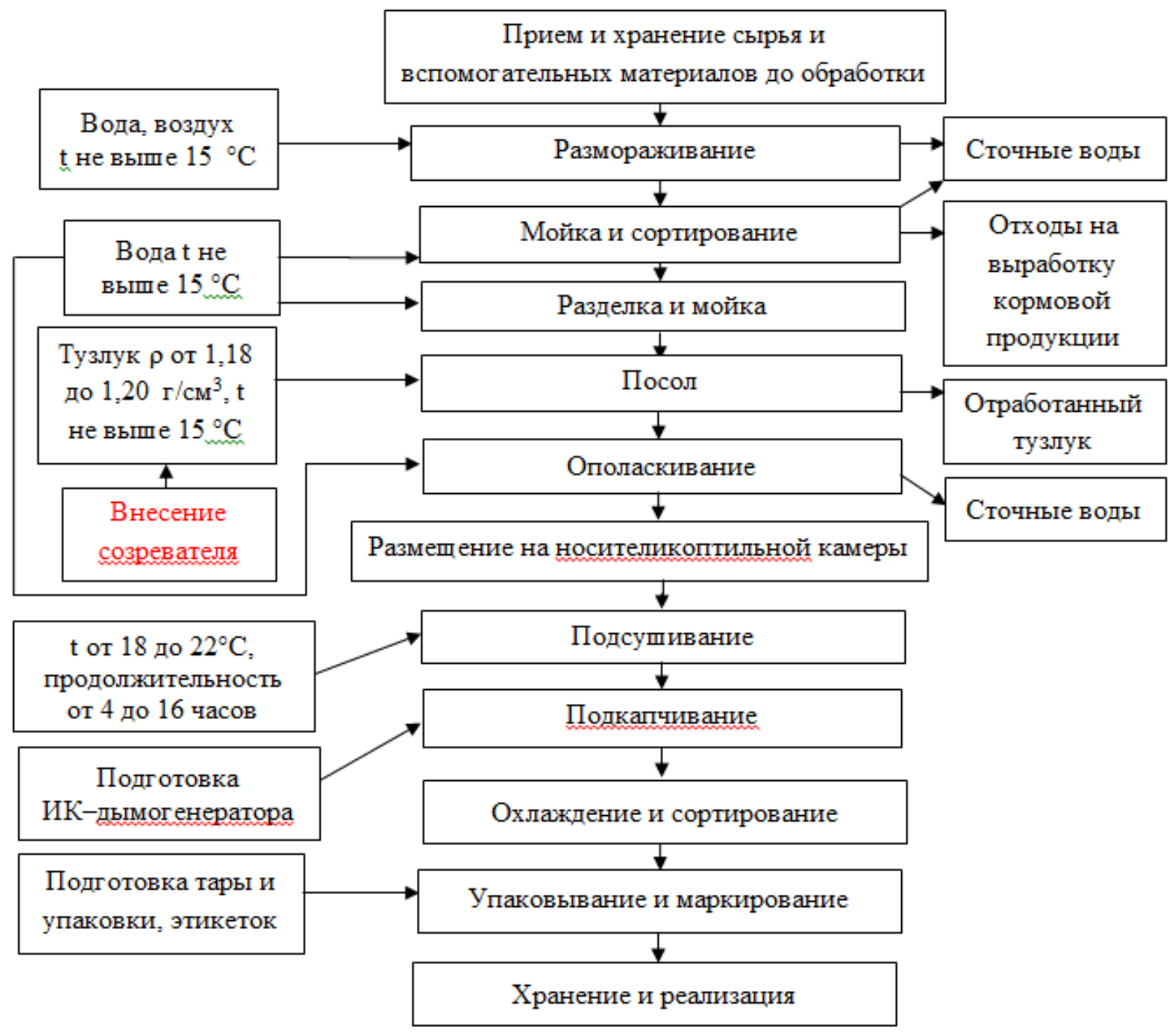

Рис. 1. Технологическая схема изготовления филе окуня морского подкопченного деликатесного

Таблица 4

\section{Условия посола филе окуня морского}

\begin{tabular}{|c|c|c|c|c|}
\hline \multirow[b]{2}{*}{ Созреватель } & \multicolumn{4}{|c|}{ Параметры посола } \\
\hline & $\begin{array}{c}\text { концентрация } \\
\text { созревателя в } \\
\text { тузлуке, \% }\end{array}$ & $\begin{array}{l}\text { соотношение } \\
\text { рыба: тузлук }\end{array}$ & $\begin{array}{c}\text { температура } \\
\text { тузлука, }{ }^{\circ} \mathrm{C}\end{array}$ & $\begin{array}{c}\text { длительность } \\
\text { посола филе с } \\
\text { кожей, мин }\end{array}$ \\
\hline $\begin{array}{c}\text { ФПГПКС } \\
\text { (контроль) }\end{array}$ & 0,04 & $1: 1$ & $8 \pm 1$ & 15 \\
\hline $\begin{array}{c}\text { КПД } \\
\text { «Pre-Fish» }\end{array}$ & от 3,0 до 5,0 & $1: 2$ & $8 \pm 1$ & от 10 до 20 \\
\hline
\end{tabular}


Гистограмма на рис. 2 представляет результаты определения зависимости выхода соленого полуфабриката от использованного созревателя и его концентрации в случае с КПД «Pre-Fish».

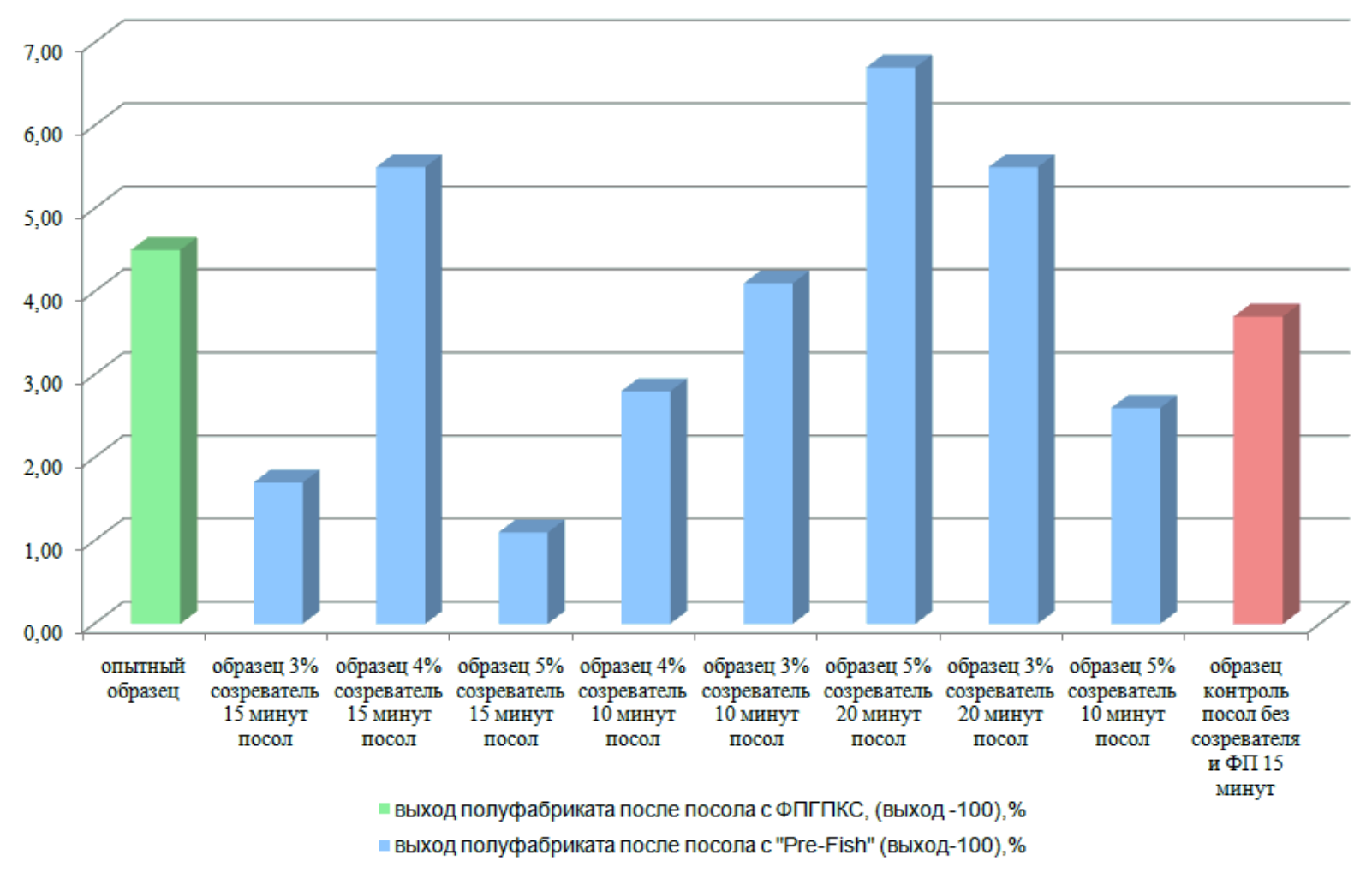

Рис. 2. Зависимость выхода (превышение от $100 \%$ ) соленого полуфабриката от использованного созревателя и его концентрации в тузлуке (в случае ПД «Pre-Fish»)

Как видно из рис. 2, во всех случаях использования созревателя выход соленого полуфабриката превышает $100 \%$ на величину от 1 до $7 \%$.

При этом посол полуфабриката при выбранных условиях без созревателя также обеспечивает выход более $100 \%$, однако превышение меньше, чем в случае с ФПГПКС и в отдельных вариантах посола полуфабриката с КПД «Pre-Fish».

В ходе работы также устанавливали выход готовой продукции подкопченного филе окуня (рис. 3). Процесс подкапчивания осуществляли дымо-воздушной смесью (ДВС), получаемой смешением дыма от ИКдымогенератора с воздухом. Температура ДВС составляла от 20 до $26^{\circ} \mathrm{C}$ и относительной влажностью от 55 до $60 \%$, скорость циркуляции ДВС в коптильной камере составляла от 0,1 до 0,3 м/с, длительность подкапчивания от 6 до 8 часов. 


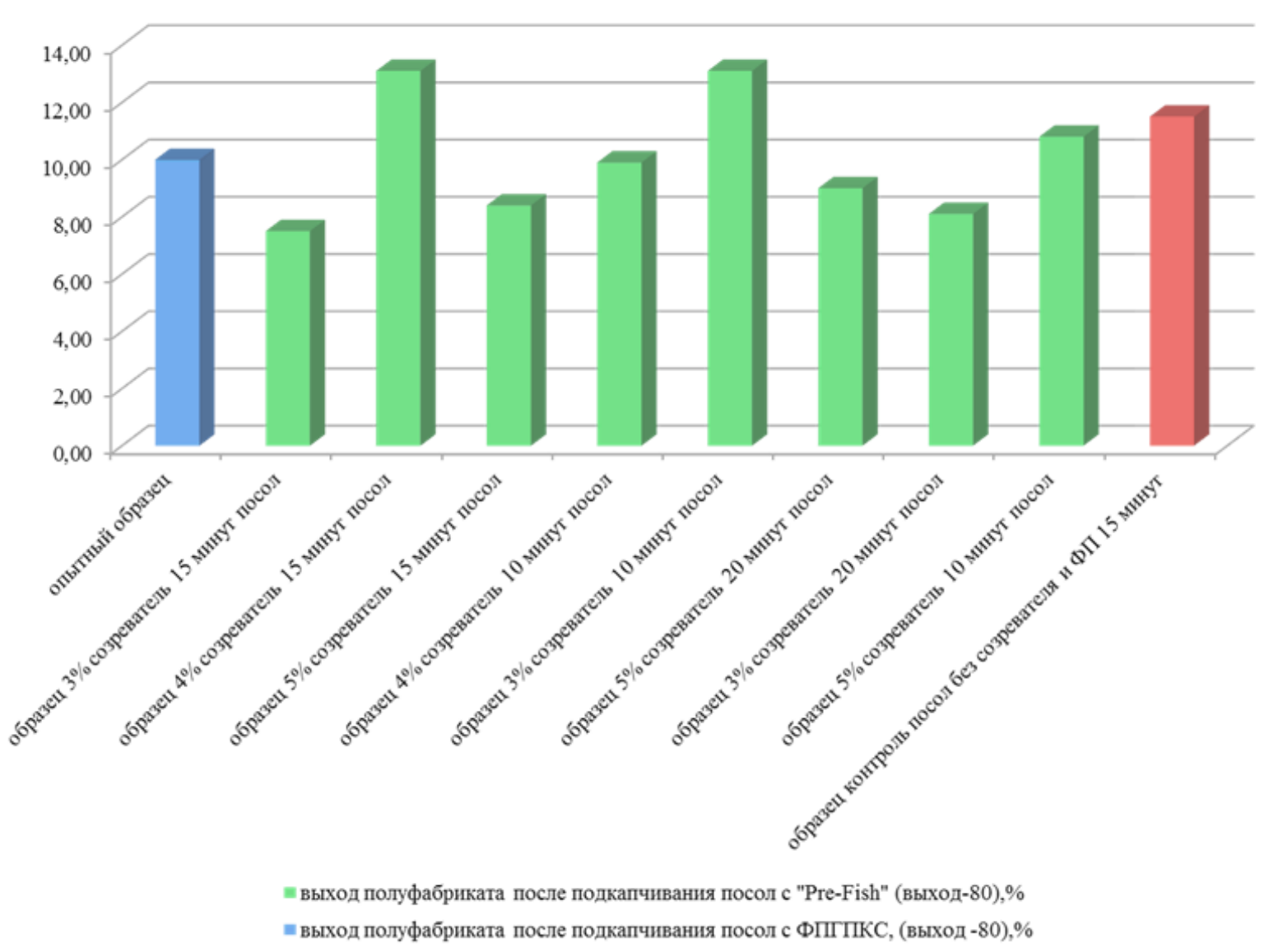

\section{Рис. 3. Выход готовой подкопченной продукции в зависимости от условий посола полуфабриката}

Из гистограммы на рис. 3 видно, что выход подкопченного филе менее 100 \% во всех случаях, потери массы относительно полуфабриката составляют около $10 \%$, при этом четкой зависимости выхода готовой продукции от условий посола не выявлено.

Следующим этапом исследований было изучение влияния КПД «Pre-Fish» на интенсивность процесса созревания филе окуня как на этапе посола, так и на этапе хранения готовой подкопченной продукции. Интенсивность созревания оценивали по показателям буферной емкости и общей кислотности филе, а также по органолептическим и реологическим показателям. Результаты исследования представлены в таблице 5. 
Таблица 5

\section{Результаты комплексных исследований интенсивности процесса} созревания полуфабриката на этапах посола и хранения готовой продукции - филе окуня морского подкопченного в зависимости от

технологических режимов посола

\begin{tabular}{|c|c|c|c|c|c|c|}
\hline \multirow{2}{*}{$\begin{array}{c}\text { Характеристика } \\
\text { посола: } \\
\text { концентрация } \\
\text { созревателя, \%, и } \\
\text { длительность } \\
\text { посола, мин }\end{array}$} & \multirow{2}{*}{$\begin{array}{l}\text { АЛО } \\
\text { мГ\% }\end{array}$} & \multirow[b]{2}{*}{$\begin{array}{c}\mathrm{OK} \\
\%\end{array}$} & \multirow[b]{2}{*}{$\begin{array}{c}\text { Буферность } \\
\text {, }{ }^{\circ} \mathrm{T}\end{array}$} & \multicolumn{2}{|c|}{$\begin{array}{c}\text { Реологические } \\
\text { показатели }\end{array}$} & \multirow{2}{*}{$\begin{array}{c}\text { Органолепти- } \\
\text { ческие } \\
\text { показатели }\end{array}$} \\
\hline & & & & $\begin{array}{c}\text { усилие } \\
\text { резания, } \\
\text { Н }\end{array}$ & $\begin{array}{c}\text { твердость, } \\
\text { Н }\end{array}$ & \\
\hline \multicolumn{7}{|c|}{ Посол в тузлуке с добавлением КПД «Pre-Fish» } \\
\hline $3 \%, 15$ минут & 29,45 & 0,24 & 10 & 17,64 & 0,85 & 4,32 \\
\hline $4 \%, 15$ минут & 18,11 & 0,15 & 20 & 5,04 & 1,67 & 3,04 \\
\hline $5 \%, 15$ минут & 18,11 & 0,21 & 20 & 17,40 & 3,42 & 4,79 \\
\hline $4 \%, 10$ минут & 2,78 & 0,21 & 25 & 3,78 & 1,09 & 3,10 \\
\hline $3 \%, 10$ минут & 11,05 & 0,18 & 20 & 13,70 & 5,48 & 4,62 \\
\hline $5 \%, 20$ минут & 2,78 & 0,18 & 20 & 36,30 & 4,26 & 5,00 \\
\hline $3 \%, 20$ минут & 4,19 & 0,18 & 20 & 19,68 & 2,64 & 4,50 \\
\hline $5 \%, 10$ минут & 1,39 & 0,19 & 20 & 6,08 & 1,58 & 3,00 \\
\hline $\begin{array}{c}\text { Контроль - посол } \\
\text { без созревателя, } \\
15 \text { минут }\end{array}$ & 20,96 & 0,18 & 0 & 18,41 & 2,02 & 4,08 \\
\hline
\end{tabular}

Для оценки биохимических изменений использовали показатели, свидетельствующие о глубине гидролитических процессов, как под действием собственных ферментов рыбы, так и под действием добавляемого при посоле созревателя - общую кислотность в процентах в пересчете на уксусную кислоту и буферность. Оба показателя косвенно свидетельствуют о накоплении кислых продуктов распада преимущественно белков, в том числе свободных аминокислот.

Анализ таблицы 5 показал, что применение созревателя на этапе посола существенно сказывается на показателях, характеризующих микробиологические изменения в продукции (АЛО), а также показателях созревания - буферной ёмкости, что естественным образом отражается на органолептической оценке продукции и ее реологических показателях - усилии резания и твердости. 
По итогам проведенных исследований сформулированы выводы:

1. Исследован химический состав филе окуня морского и определены характеризующие его отдельные технохимические свойства.

2. Исследованы биохимические процессы, протекающие в тканях филе окуня морского на этапе посола полуфабриката с использованием созревателя натурального происхождения - ферментного препарата из гепатопанкреаса краба-стригуна и созревателя «Pre-Fish», а также на этапе хранения готовой продуции в зависимости от параметров тузлучного посола.

3. Разработаны рекомендации по посолу полуфабриката - филе окуня морского в технологии деликатесной подкопченной продукции.

4. Экспериментально установлено, что оптимальной концентрацией КПД «Pre-Fish» при тузлучном посоле филе окуня морского в технологии деликатесной подкопченной продукции является концентрация 5,0 \%, длительность посола 15 минут.

\section{Список литературы}

1. Шкуратова Е.Б. Разработка технологии деликатесного подкопченного филе тресковых рыб с использованием ферментного препарата из гепатопанкреаса краба стригуна опилио (Chionoecetes opilio) : спец. 05.18.04 «Технология мясных, молочных и рыбных продуктов и холодильных производств» и 05.18.07 «Биотехнология пищевых продуктов и биологически активных веществ»: автореф. дис. ... канд. техн. наук/ Шкуратова Евгения Борисовна: Мурман.гос. техн. ун-т.- Мурманск, 2019. - 24 с. : ил.

2. Шкуратова Е.Б., Шокина Ю.В., Мухин В.А. Разработка технологии деликатесной подкопченной продукции из тресковых рыб с использованием ферментного препарата из гепатопанкреаса краба-стригуна Chionoecetesopilio / Е.Б. Шкуратова, Ю.В. Шокина., В.А. Мухин // Вестник ВГУИТ. - 2017. - № 2. C. $126-137$.

3. Об утверждении Стратегии развития рыбохозяйственного комплекса Российской Федерации на период до 2030 года (вместе с «Планом мероприятий по реализации стратегии развития рыбохозяйственного комплекса Российской Федерации на период до 2030 года»): Распоряжение Правительства Рос. Федерации № 2798-р: от 26 ноября 2019 г. // Собрание законодательства Российской Федерации. - 2019. - № 48. - Ст. 6905. 